\title{
Protection of mice against vaginal colonisation by Mycoplasma pulmonis
}

\author{
D. TAYLOR-ROBINSON and P. M. FURR \\ Division of Sexually Transmitted Diseases, Clinical Research Centre, Watford Road, Harrow, Middlesex HA1 3 UJ
}

\begin{abstract}
Summary. Resistance against vaginal colonisation by Mycoplasma pulmonis in strain TO mice after exposure to the mycoplasma was investigated. Eighteen mice from which $M$. pulmonis had been eliminated from the vagina, either naturally or by antibiotic therapy, were resistant to vaginal recolonisation. Specific antibody was measured by an indirect microimmunofluorescence technique and the geometric mean titre (GMT) for each group of mice is presented. Almost all of 31 mice that had developed circulating antibody (GMT 83) or local antibody (GMT 40), or both, after vaginal exposure were resistant to re-colonisation, as were those in which antibodies could not be detected. Seven other mice which had been colonised only in the oropharynx previously and which possessed antibody-circulating (GMT 64) or local (GMT30), or both-were resistant to vaginal colonisation, but 13 mice with little or no antibody after lack of colonisation at either anatomical site were susceptible. All of 15 mice given killed $M$. pulmonis organisms intravenously, despite developing circulating antibody in high titre (GMT 122), were susceptible to vaginal colonisation, as were 14 of 15 mice that developed circulating (GMT 15) and local antibodies after being given killed organisms intravaginally. However, 25 mice with high titres of circulating (GMT 154-170) or local (GMT 20) antibody, or both, after receiving live organisms intravenously, were less susceptible to vaginal colonisation (17 becoming colonised) than were 21 non-immunised mice (all becoming colonised) and the organisms were eradicated more rapidly from the former. Despite this, the mice that were colonised following intravenous inoculation of live organisms had pre-challenge antibody titres that were as great as those that were not colonised. The results indicate that vaginal protection is likely to be mediated by factors other than, or in addition to, antibody, presumably by a cell-mediated means, and that concurrent respiratory infections are likely to contribute to vaginal immunity.
\end{abstract}

\section{Introduction}

Mycoplasma pulmonis usually causes respiratory disease in mice. However, treatment of female mice with progesterone predisposes them to mycoplasmal colonisation of the genital tract. ${ }^{1}$ Natural clearance of the organisms from the genital tract occurs eventually, after which the animals have been shown to be resistant to re-colonisation following intravaginal challenge. ${ }^{2}$ The role of serum and local lower genital tract antibodies and of other immunological factors in this protection has not been assessed. Furthermore, it is not known whether the respiratory tract mycoplasmal infection that nearly always occurs after genital tract colonisation with $M$. pulmonis makes any contribution to genital tract resistance. This report describes observations that go some way toward resolving these questions.

\section{Materials and methods}

Mice

Female mice of strain TO were used when 6-8 weeks old. They had been bred in the Specific Pathogen-free Unit at the Clinical Research Centre. Animals were checked by a culture procedure ${ }^{3}$ for indigenous $M$. pulmonis infection of the respiratory and genital tracts before commencement of the experiments.

\section{Progesterone}

Depo-Provera (Upjohn Ltd, Crawley, Sussex) was injected subcutaneously $(2.5 \mathrm{mg}$ in $0.2 \mathrm{ml}) 1$ week before, at the time of, and 1 and 2 weeks after all intravaginal inoculations with $M$. pulmonis.

\section{Mycoplasma medium}

Glucose-containing medium used for the growth 
and isolation of $M$. pulmonis has been described previously. ${ }^{4}$

\section{M. pulmonis inoculum}

M. pulmonis, strain $\mathrm{JB},{ }^{5}$ is able to produce pneumonia, arthritis and genital tract disease in mice. ${ }^{1}$ The organisms for the mouse inocula were grown in liquid medium that was incubated at $37^{\circ} \mathrm{C}$ for 3 days and their number was determined by making serial 10 -fold dilutions in medium: the highest dilution at which the colour of the medium changed from red to yellow during incubation at $37^{\circ} \mathrm{C}$ was considered to contain one colour-changing unit (ccu) of $M$. pulmonis. ${ }^{3}$ In almost all experiments, the inocula comprised organisms of low sequential passage in liquid medium (designated p.0), but a few mice received organisms that had been passed in such medium 10 or 50 times (designated p.10 or p.50). ${ }^{2}$ All inocula contained $5 \times 10^{7} \mathrm{ccu} / \mathrm{ml}$. In some experiments, the organisms in such inocula were killed by heating at $56^{\circ} \mathrm{C}$ for $30 \mathrm{~min}$.

\section{Intravaginal inoculation}

Mice were anaesthetised by intraperitoneal administration of a mixture of one part Hypnorm (Janssen Pharmaceutical Ltd, Oxford), two parts water and one part Hypnovel (Roche Products Ltd, Welwyn Garden City, Herts) (10 ml/kg body weight) and then inoculated intravaginally with $50 \mu \mathrm{l}$ of the $M$. pulmonis inoculum, with a Finnpipette (Jencons Scientific Ltd, Leighton Buzzard, Beds), the inoculation coinciding with the second of the four progesterone injections.

\section{Serum samples}

Mice were bled from the tail vein and the sera were separated by centrifugation of the blood at $2500 \mathrm{rpm}$ for $10 \mathrm{~min}$.

\section{Vaginal washings}

These were procured by introducing $50 \mu \mathrm{l}$ of phosphate-buffered saline (PBS) into the vagina with a Finnpipette (Jencons) and withdrawing it; this was repeated twice more with the same PBS.

\section{Cytology and recovery of mycoplasmas}

To determine the stage of the reproductive cycle, a plain cotton-wool nasopharyngeal swab (MW142; Medical Wire and Equipment Co. Ltd, Corsham, Wiltshire) was inserted and rotated in the vagina, withdrawn and rolled on a glass slide. The same swab was re-inserted in the vagina, withdrawn and the contents expressed in $1.8 \mathrm{ml}$ of liquid medium. This was designated a 10-fold dilution, and further dilutions were made in 10-fold steps, usually to $10^{8}$, to assess (as described above) the number of $M$. pulmonis organisms present in the specimen. Other nasopharyngeal swabs were introduced into the oropharynx and their contents were expressed in the mycoplasmal medium which was titrated as described above. The geometric mean titre (GMT) of organisms was calculated for all mice within a group and not just for those that were mycoplasma-positive.

The vaginal smears were fixed in methanol for $30 \mathrm{~min}$, stained with Giemsa for $30 \mathrm{~min}$ and examined microscopically.

\section{Antibody measurement}

Sera and vaginal washings were examined for antibody to $M$. pulmonis (strain JB) by means of a quantitative indirect micro-immunofluorescence technique. A rabbit polyvalent (IgM, IgG) antiserum or a rabbit anti-IgA, followed by a fluorescein-labelled goat anti-rabbit serum, were used as described previously. ${ }^{6}$ The antibody titres of sera or vaginal washings are presented and the GMT of antibody was calculated for all mice within a group and not just for those possessing antibody.

\section{Results}

Protection against vaginal colonisation of mice by $M$. pulmonis following previous colonisation and elimination of the organisms by lymecycline

Previously we showed that mice of TO and CBA strains that had recovered spontaneously, after many months, from vaginal colonisation by $M$. pulmonis were resistant to re-challenge. ${ }^{2}$ The question of whether colonisation for a relatively short time would provide protection was, therefore, addressed. Of 20 strain TO mice that had been inoculated intravaginally with $M$. pulmonis, 18 were still colonised after 40 days. These mice were then treated with the antibiotic, lymecycline (6 mg in $0.2 \mathrm{ml}$, subcutaneously, each day for 10 days). After a further 10 days, only one mouse remained colonised. None of these mice was colonised 14 days later and they, together with a group of 10 mice of similar age, unexposed previously to $M$. pulmonis or antibiotic, were inoculated intravaginally with the mycoplasma. Fifteen of the 18 mice that had received $M$. pulmonis previously did not become colonised vaginally and the remaining three did so for a short period only, whereas all of the 10 mice not previously inoculated with $M$. pulmonis became colonised (table I).

Relationship of serum and local antibody to protection against vaginal colonisation by $M$. pulmonis

Observations after initial vaginal colonisation. Thirty-one mice were inoculated intravaginally, most 
Table I. Assessment of protection against re-colonisation in mice initially colonised vaginally with $M$. pulmonis and treated with lymecycline to eliminate the organisms

\begin{tabular}{|c|c|c|c|c|}
\hline \multirow{2}{*}{$\begin{array}{l}\text { Number of mice } \\
\text { challenged } \\
\text { vaginally }\end{array}$} & \multirow{2}{*}{$\begin{array}{l}\text { Number of mice } \\
\text { colonised in } \\
\text { the vagina } \\
\text { previously }\end{array}$} & \multicolumn{3}{|c|}{$\begin{array}{l}\text { Number of mice colonised vaginally, } \\
\text { (organism titre range) and GMT on } \\
\text { indicated day after challenge }\end{array}$} \\
\hline & & 7 & 21 & 162 \\
\hline 18 & $18^{*}$ & $\begin{array}{c}3 \\
\left(10^{1}-10^{3}\right) \\
3 \cdot 1 \times 10^{0}\end{array}$ & 0 & 0 \\
\hline 10 & $0 \dagger$ & $\begin{array}{c}10 \\
\left(10^{6}-10^{8}\right) \\
3.9 \times 10^{6}\end{array}$ & $\begin{array}{c}10 \\
\left(10^{6}-10^{8}\right) \\
1.6 \times 10^{7}\end{array}$ & $\begin{array}{c}6 \\
\left(10^{1}-10^{6}\right) \\
2 \cdot 5 \times 10^{2}\end{array}$ \\
\hline
\end{tabular}

* These mice were colonised previously with $M$. pulmonis for 40 days, treated with lymecycline for 10 days and challenged 24 days later when the organisms had been eradicated from all of the mice.

$\dagger$ These mice were not inoculated previously with $M$. pulmonis, nor given antibiotic.

Table II. Relationship between antibody and susceptibility to vaginal colonisation in mice colonised in the vagina previously

\begin{tabular}{|c|c|c|c|c|c|c|}
\hline \multicolumn{3}{|c|}{ Antibody before vaginal re-challenge } & \multirow{2}{*}{$\begin{array}{c}\text { Number } \\
\text { of mice } \\
(\mathrm{n}=31)\end{array}$} & \multicolumn{2}{|c|}{ Number of mice colonised previously in } & \multirow{2}{*}{$\begin{array}{c}\text { Number of mice } \\
\text { protected after } \\
\text { vaginal re-challenge }\end{array}$} \\
\hline Site & Titre range & GMT & & vagina & oropharynx & \\
\hline Circulating & $16->256$ & 83 & 25 & 25 & 24 & 25 \\
\hline Local & $8-128$ & 40 & 30 & 30 & 29 & 30 \\
\hline Circulating & $4-8$ & 7 & 6 & 6 & 6 & 6 \\
\hline Local & 4 & 4 & 1 & 1 & 1 & 1 \\
\hline
\end{tabular}

of them with p.0 of $M$. pulmonis. They became colonised vaginally and 8 months later, when the organisms could no longer be recovered from the vagina, these mice were re-challenged intravaginally with $M$. pulmonis. Blood and vaginal washings were collected for antibody measurement before re-challenge and the relationship between the presence of antibody and susceptibility to vaginal colonisation is shown in table II. Thirty of the 31 mice became colonised in the oropharynx subsequent to the first intravaginal inoculation. Thus, there was only one mouse that had been colonised vaginally but not in the oropharynx prior to vaginal re-challenge; this mouse was resistant to vaginal recolonisation. Twenty-five of the mice developed circulating antibody (GMT 83) and these, together with five of the remaining six, developed local antibody (GMT 40) following vaginal and oropharyngeal colonisation. Local secretory IgA antibody was not detected. On vaginal re-challenge, all the mice were resistant to vaginal recolonisation. It is apparent (table II) that although six of the 31 mice had only low titres of circulating antibody, five of the six had local antibody and all six were resistant vaginally.

Twenty-two mice were inoculated intravaginally, most of them with p. 10 or p.50 of $M$. pulmonis. None of them became colonised vaginally but seven did so in the oropharynx. Eight months later, after specimens had been collected for antibody measurement, the mice were re-challenged vaginally and the results are shown in table III. Eight of the mice developed circulating antibody (GMT 64) and these, together with one other, developed local antibody (GMT 30) as a result of becoming colonised only in the oropharynx. On vaginal re-challenge, seven of the mice were resistant to vaginal re-colonisation. However, of 13 mice with little or no circulating or local antibody following lack of colonisation at either site (apart from one mouse colonised in the oropharynx), none was resistant to re-colonisation.

Observations after intravenous inoculation with live or killed M. pulmonis organisms. To assess further the role of antibody in protecting mice against vaginal colonisation, 15 mice were inoculated intravenously twice, 3 weeks apart, with $5 \times 10^{8} \mathrm{ccu}$ of live $M$. pulmonis organisms and 15 mice were inoculated likewise with heat-killed organisms. Two weeks after the second inoculation, these mice and 15 others that had not been inoculated were bled for assessment of antibody and then challenged intravaginally with $M$. pulmonis. The relationship between the presence of circulating antibody and protection against vaginal colonisation is shown in table IV. Most M. pulmonisimmunised mice, irrespective of whether they received live or killed organisms, developed high titres of antibody. However, the mice that had received killed organisms, which had stimulated high titres of antibody (GMT 122), were fully susceptible to vaginal colonisation, the majority still being colonised with moderately large numbers of organisms after 49 days. Indeed, such mice were as susceptible as those that had little or no antibody after receiving mycoplasma broth only. In contrast, intravenous inoculation of mice with 
Table III. Relationship between antibody and susceptibility to vaginal colonisation in mice not colonised in the vagina previously

\begin{tabular}{|c|c|c|c|c|c|c|}
\hline \multicolumn{3}{|c|}{ Antibody before vaginal re-challenge } & \multirow{2}{*}{$\begin{array}{l}\text { Number } \\
\text { of mice } \\
(n=22)\end{array}$} & \multicolumn{2}{|c|}{ Number of mice colonised previously in } & \multirow{2}{*}{$\begin{array}{c}\text { Number of mice } \\
\text { protected after } \\
\text { vaginal re-challenge }\end{array}$} \\
\hline Site & Titre range & GMT & & vagina & oropharynx & \\
\hline Circulating & $16-128$ & 64 & 8 & 0 & 7 & 7 \\
\hline Local & $8-128$ & 30 & 9 & 0 & 6 & 7 \\
\hline Circulating & $<2-8$ & 3 & 14 & 0 & 0 & 0 \\
\hline Local & $<2-4$ & 2 & 13 & 0 & 1 & 0 \\
\hline
\end{tabular}

Table IV. Relationship between circulating antibody produced by live or killed $M$. pulmonis given intravenously to mice and vaginal colonisation after vaginal challenge

\begin{tabular}{|c|c|c|c|c|c|c|}
\hline \multirow{2}{*}{$\begin{array}{l}\text { Intravenous } \\
\text { inoculum }\end{array}$} & \multirow{2}{*}{$\begin{array}{l}\text { Number of } \\
\text { mice in } \\
\text { experiment }\end{array}$} & \multirow{2}{*}{$\begin{array}{l}\text { Number of mice } \\
\text { with antibody } \\
\text { (antibody titre } \\
\text { range) and GMT }\end{array}$} & \multicolumn{4}{|c|}{$\begin{array}{l}\text { Number of mice colonised (organism titre range) and } \\
\text { GMT on indicated day after intravaginal inoculation }\end{array}$} \\
\hline & & & 7 & 21 & 35 & 49 \\
\hline \multirow{3}{*}{$\begin{array}{l}\text { Live } \\
\text { M. pulmonis }\end{array}$} & 15 & 15 & 11 & 8 & 5 & 3 \\
\hline & & $(16->512)$ & $\left(10^{3}-10^{8}\right)$ & $\left(10^{4}-10^{6}\right)$ & $\left(10^{2}-10^{7}\right)$ & $\left(10^{3}-10^{5}\right)$ \\
\hline & & 154 & $6.3 \times 10^{3}$ & $3.9 \times 10^{2}$ & $1.5 \times 10^{1}$ & $5.0 \times 10^{0}$ \\
\hline \multirow{3}{*}{$\begin{array}{l}\text { Killed } \\
M . \text { pulmonis }\end{array}$} & 15 & 13 & 15 & 15 & 15 & 11 \\
\hline & & $(16->512)$ & $\left(10^{6}-10^{8}\right)$ & $\left(10^{4}-10^{7}\right)$ & $\left(10^{2}-10^{8}\right)$ & $\left(10^{1}-10^{8}\right)$ \\
\hline & & 122 & $1.9 \times 10^{6}$ & $1.5 \times 10^{5}$ & $2.5 \times 10^{5}$ & $2.0 \times 10^{3}$ \\
\hline \multirow[t]{3}{*}{ Mycoplasma broth } & 13 & 2 & 13 & 13 & 13 & 11 \\
\hline & & $(<2-8)$ & $\left(10^{5}-10^{8}\right)$ & $\left(10^{3}-10^{7}\right)$ & $\left(10^{4}-10^{8}\right)$ & $\left(10^{3}-10^{7}\right)$ \\
\hline & & 5 & $2.0 \times 10^{6}$ & $1.4 \times 10^{5}$ & $3.4 \times 10^{6}$ & $4.8 \times 10^{4}$ \\
\hline
\end{tabular}

Table V. Relationship between circulating and local antibody produced by live $M$. pulmonis given intravenously to mice and vaginal colonisation after vaginal challenge

\begin{tabular}{|c|c|c|c|c|c|c|c|c|}
\hline \multirow{2}{*}{$\begin{array}{l}\text { Intravenous } \\
\text { inoculum }\end{array}$} & \multirow{2}{*}{$\begin{array}{l}\text { Number of } \\
\text { mice in } \\
\text { experiment }\end{array}$} & \multicolumn{3}{|c|}{ Antibody before vaginal challenge } & \multicolumn{4}{|c|}{$\begin{array}{l}\text { Number of mice colonised (organism titre range) and } \\
\text { GMT on indicated day after intravaginal inoculation }\end{array}$} \\
\hline & & Site & $\begin{array}{l}\text { Titre } \\
\text { range }\end{array}$ & GMT & 7 & 21 & 35 & 49 \\
\hline $\begin{array}{l}\text { Live } \\
M . \text { pulmonis }\end{array}$ & 10 & $\begin{array}{l}\text { Circulating } \\
\text { Local }\end{array}$ & $\begin{array}{l}64->512 \\
8-64\end{array}$ & $\begin{array}{r}170 \\
20\end{array}$ & $\begin{array}{c}6 \\
\left(10^{1}-10^{7}\right) \\
1 \cdot 5 \times 10^{3}\end{array}$ & $\begin{array}{c}3 \\
\left(10^{1}-10^{7}\right) \\
2 \cdot 5 \times 10^{1}\end{array}$ & $\begin{array}{c}2 \\
\left(10^{6}\right) \\
1 \cdot 5 \times 10^{1}\end{array}$ & $\begin{array}{c}2 \\
\left(10^{6}\right) \\
1.5 \times 10^{1}\end{array}$ \\
\hline Mycoplasma broth & 8 & $\begin{array}{l}\text { Circulating } \\
\text { Local }\end{array}$ & $\begin{array}{l}<4-8 \\
<4-8\end{array}$ & $\begin{array}{l}6 \\
4 \cdot 7\end{array}$ & $\begin{array}{c}8 \\
\left(10^{6}-10^{7}\right) \\
3.9 \times 10^{6}\end{array}$ & $\begin{array}{c}8 \\
\left(10^{6}-10^{8}\right) \\
1 \cdot 2 \times 10^{7}\end{array}$ & $\begin{array}{c}8 \\
\left(10^{7}-10^{8}\right) \\
1.5 \times 10^{7}\end{array}$ & $\begin{array}{c}8 \\
\left(10^{5}-10^{7}\right) \\
3.9 \times 10^{6}\end{array}$ \\
\hline
\end{tabular}

live organisms afforded some protection, since only 11 of 15 became colonised vaginally and this number had fallen to three after 49 days. Furthermore, the numbers of organisms recovered from the vaginas of the latter mice were at least 1000 -fold less than those from the other two groups of mice (table IV). The unlikely role of antibody in this protection may be deduced from the fact that the pre-challenge level of antibody in the 11 mice that became colonised after receiving live organisms was actually greater (GMT 200) than that in the four mice that did not become colonised (GMT 76).

In a further experiment (table V), the relationship of the levels of circulating and local antibody, stimulated by live organisms given intravenously, to resistance against vaginal colonisation was explored. As before, there was clear evidence of partial protection in the presence of both circulating (GMT 170) and local (GMT 20) antibody. Thus, four of 10 immunised mice did not become colonised vaginally and those that were colonised possessed smaller numbers of organisms and eliminated them from the vagina faster than did the eight mice that had received mycoplasma medium only and had not developed antibodies. However, the GMT of circulating and local antibodies before challenge for the four mice that did not become colonised vaginally ( 224 and 16 , respectively) was little different from that for the six mice that did become colonised (150 and 24, respectively).

Observations after intravaginal inoculation with killed $M$. pulmonis organisms. Fifteen mice were each inoculated intravaginally with $2.5 \times 10^{7}$ of killed $M$. pulmonis organisms on two occasions 2 weeks apart. This stimulated moderate titres of circulating antibody (range < 4-256; GMT 15) and local antibody, but no protection against intravaginal challenge 2 weeks after the second immunisation. Thus, 14 of the mice given killed organisms became colonised vaginally and 10 
of these were still colonised 7 weeks later. This outcome was similar to that for 15 mice that were not immunised, all of which became colonised, nine remaining so 7 weeks later.

\section{Discussion}

Our original observations on the protection against vaginal re-colonisation by $M$. pulmonis afforded to mice that had been colonised vaginally many months previously ${ }^{2}$ did not answer the question of how such immunity was established. We believe that our present observations throw some light on the immune mechanisms involved. In the first place, we have established that $M$. pulmonis organisms do not have to be eliminated from the vagina naturally, a process which may take many months, for the mice to be rendered immune to vaginal re-colonisation. Thus, mice which had a vaginal infection curtailed by antibiotic therapy shortly after it had become established were also resistant to vaginal re-colonisation. It seems unlikely that this was due to any residual antibiotic as the last dose was given $>3$ weeks before colonisation was attempted.

The impression obtained early in this work was that antibodies (circulating or local, or both) were important in vaginal protection, as mice in which such antibodies were found were resistant to re-colonisation and most of those in which they were not found were susceptible. However, there are several factors which indicate that stimulation of antibody, even in the vagina, is not crucial in resistance to vaginal colonisation. Firstly, antibody titres after intravenous inoculation of killed organisms were as great as those stimulated by vaginal colonisation; however, whereas the latter prevented re-colonisation, intravenous inoculation with killed organisms failed to provide any vaginal protection. Secondly, some mice were afforded vaginal protection by live organisms given intravenously, which again stimulated high titres of antibodies, but such titres were no greater in mice that were subsequently resistant to vaginal colonisation

\section{References}

1. Furr PM, Taylor-Robinson D. Enhancement of experimental Mycoplasma pulmonis infection of the mouse genital tract by progesterone treatment. $J$ Hyg 1984; 92 : 139-144.

2. Taylor-Robinson D, Furr PM. Immunity to mycoplasmal infection of the genital tract: a mouse model. Immunology $1986 ; 58: 239-243$.

3. Taylor-Robinson D. Genital mycoplasma infections. Clin Lab Med 1989; 9: 501-523.

4. Manchee RJ, Taylor-Robinson D. Haemadsorption and haemagglutination by mycoplasmas. J Gen Microbiol 1968; 50: $465-478$. than they were in those that were susceptible. Thirdly, administration of killed organisms intravaginally, which stimulated moderate titres of both circulating and local antibodies, failed to provide any protection against vaginal colonisation. Fourthly, a few mice in which antibody, either circulating or local, had not been stimulated by previous vaginal colonisation, were fully protected against re-colonisation. It is possible that failure to detect antibody, including $\operatorname{IgA}$, in these vaginal washings was due to the technique being insufficiently sensitive to detect low levels that might, nevertheless, have been protective. Certainly, in respiratory infections by $M$. pneumoniae in $\operatorname{man}^{7}$ and by $M$. pulmonis in mice, ${ }^{8}$ local antibody seems to play an important part in protection against re-infection. However, the mechanisms may not be the same at each anatomical site, nor the same in different species, nor with different mycoplasmas. Indeed, overall, these observations strongly suggest that protection is likely to be mediated by factors other than, or at least in addition to, antibody, perhaps by a cell-mediated means.

One of the problems in establishing the extent to which vaginal colonisation by $M$. pulmonis leads to immunity at this site is that it is difficult-indeed almost impossible - to prevent infection of the respiratory tract also occurring after the introduction of $M$. pulmonis into the vagina. Vaginal, without oropharyngeal, colonisation before vaginal challenge was seen in only one mouse, an animal which, incidentally, was resistant to the challenge. Thus, although it is clear that vaginal colonisation may, of itself, provide immunity to re-colonisation, the possibility that a concurrent respiratory infection is an important contributor to vaginal immunity needs to be taken into consideration. This seems likely because a few mice that were not colonised vaginally, but were colonised oropharyngeally, after intravaginal inoculation of $M$. pulmonis organisms that had been passed frequently in liquid medium, were then immune to vaginal challenge. This issue and the role of cell-mediated mechanisms in immunity to vaginal colonisation need to be explored.
5. Barden JA, Tully JG. Experimental arthritis in mice with Mycoplasma pulmonis. J Bacteriol 1969; 100 : 5-10.

6. Furr PM, Taylor-Robinson D. Microimmunofluorescence technique for detection of antibody to Mycoplasma genitalium. $J$ Clin Pathol 1984; 37: 1072-1074.

7. Brunner H, Greenberg HB, James WD, Horswood RL, Couch RB, Chanock RM. Antibody to Mycoplasma pneumoniae in nasal secretions and sputa of experimentally infected human volunteers. Infect Immun 1973; 8: 612-620.

8. Taylor G, Howard CJ, Gourlay RN. Protective effect of vaccines on Mycoplasma pulmonis-induced respiratory disease of mice. Infect Immun 1977; 16: 422-431. 